\title{
PENGARUH KINERJA INDIVIDUAL DAN KEMAMPUAN TEKNIK PERSONAL PADA EFEKTIVITAS SISTEM INFORMASI AKUNTANSI DENGAN PENDIDIKAN DAN PELATIHAN SEBAGAI PEMODERASI
}

\author{
Ni Putu Ayu Kusumawati ${ }^{1)}$ \\ Putu Cita Ayu ${ }^{2)}$ \\ Universitas Hindu Indonesia, email: citaayu87@gmail.com
}

\begin{abstract}
Effectiveness of Accounting Information Systems is a system that is able to produce quality information and has been in accordance with the company's objectives in the use of the SIA.This research was conducted on LPD in Kediri District, with the number of observations as many as 63 samples obtained by purposive sampling method. The data analysis technique used is the residual test.

Individual Performance Variables have a positive coefficient of 0.458 with a significance value of $0.000<0.05$ which means Individual Performance has a positive effect on the Effectiveness of Accounting Information Systems. Hypothesis 1 in this study was accepted. The Personal Engineering Capability variable has a positive coefficient of 0.258 with a significance value of $0.045<0.05$, which means that the Personal Engineering Capability has a positive effect on the Effectiveness of Accounting Information Systems. Hypothesis 2 in this study was accepted. The moderating variable (KI and PP) has a positive coefficient of 0.037 with a significance value of $0.773>0.05$. This shows that there is no interaction between Individual Performance and Training Education in influencing the Effectiveness of Accounting Information Systems. Hypothesis 3 in this study was rejected. Moderating variables (KTP and PP) had a positive coefficient of 0.085 with a significance value of $0.508>0.05$. This shows that there is no interaction between Personal Engineering Capabilities and Training Education in influencing the Effectiveness of Accounting Information Systems. The hypothesis 4 in this study was rejected. This shows that the higher the individual performance and personal technical abilities, the effectiveness of the accounting information system will also increase. Whereas education and training do not strengthen the positive relationship between individual performance and personal technical ability to the effectiveness of accounting information systems. For SIA to be effective, individual performance and personal technical abilities must be improved so that individuals who have good performance and competency are required to operate the system. and implement accounting information systems effectively.
\end{abstract}

Keywords: individual performance, personal technical skills, effectiveness of accounting, education and training information systems.

\section{PENDAHULUAN}

Agar tercapainya tujuan suatu organisasi atau perusahaan pasti sangat memerlukan sebuah informasi untuk membuat suatu keputusan yang efektif maka di perlukannya proses 
yang merupakan kegiatan yang dilaksanakan secara terkoordinasi oleh seseorang, komputer, atau mesin (Romney dan Steinbart, 2014). Terjadinya perubahan jaman maka individu maupun perusahaan juga mengalami perubahan dalam penggunaan teknologi untuk kemajuan perusahaan (Mahendra dan Affandy, 2013). Sistem informasi akuntansi menjadi suatu alat penting di bidang teknologi informasi dan komunikasi dalam suatu organisasi atau perusahaan yang kompetitif (Ogah, 2013).

Sistem informasi akuntansi berperan penting dalam mengimplementasikan konsep. Sistem informasi akuntansi adalah sistem komputerisasi yang menggunakan komputer yang dirancang untuk mengumpulkan data, mencatat, memproses, menyimpan, dan melaporkan data dan informasi (Spermic, 2012). Sistem informasi telah dimulai pada awal tahun 1950an ketika komputer bisnis pertama tersedia dan masih dalam proses.Komputer pribadi yang kecil, cepat, dengan biaya lebih rendah telah menggantikan komputer mainframe besar. Akibatnya sistem informasi akuntansi yang sebelumnya dengan manual sekarang dilakukan oleh komputer di kebanyakan perusahaan (Awosejo et al., 2014). Metode manual yang digunakan tidak efektif karena memerlukan waktu yang lebih untuk melakukan perhitungan ulang dari awal jika terjadi kesalahan dan perubahan data, sehingga ini akan memerlukan waktu lebih untuk menghasilkan satu laporan keuangan (Krahel, 2014). Penggunaan sistem informasi pada perusahaan sekarang membantu dalam menangkap, memproses, menyimpan dan mengirimkan data dengan bantuan komputer. Akuntansi dapat membuat media tersebut sebagai alat dalam menginformasikan keadaan suatu perusahaan. Apabila informasi yang didapat buruk mungkin akan berdampak buruk juga pada pengambilan keputusan.

Sistem Informasi Akuntansi memberikan informasi keuangan yang diterjemahkan ke dalam angka dan dirumuskan dalam bentuk laporan sesuai dengan tujuannya. Instalasi 
dapat bergerak maju dalam pekerjaan mereka dengan menerima dukungan yang diperlukan untuk melaksanakan aktivitasdan mengambil keputusan yang diperlukan untuk mencapai tujuan yang diminta (Swalhah, 2014). Jadi, pengetahuan tentang sistem informasi akuntansi penting diberikan, karena informasi akuntansi memainkan peran penting dalam pengelolaan semua aktivitas suatu perusahaan. Oleh karena itu diperlukan teknologi dalam penerapannya, yaitu dengan penggunaan komputer (Medina. dkk, 2014). Sistem informasi akuntansi penting bagi organisasi ataupun perusahaan untuk meningkatkan efisiensi organisasi dan mendukung daya saing perusahaan dengan menyediakan informasi keuangan dan akuntansi bagi manajemen (Alsarayreh et al. 2011). Efektivitas penggunaan sistem informasi dalam suatu perusahaan juga harus mempertimbangkan faktor sumber daya manusia. Dalam mendukung sistem akuntansi yang dimiliki perusahaan dikenal dengan istilah kinerja individual menjadi salah satu faktor dalam keberhasilan sistem tersebut.

Kinerja individual merupakan tingkat keberhasilan seseorang secara keseluruhan selama periode tertentu di dalam melaksanakan tugas dibandingkan dengan berbagai kemungkinan hasil kerja, target, atau sasaran atau kriteria yang telah ditentukan terlebih dahulu dan telah disepakati bersama. Artinya bahwa hasil kerja seseorang merupakan evaluasi yang telah dilakukan berdasarkan periode tertentu yang akan dibandingkan dengan sasaran atau target tujuan perusahaan. Apabila kinerja seseorang tersebut diatas target yang telah disepakati, maka dapat dikatakan kinerja individu seseorang tersebut baik dan sesuai yang diharapkan. Begitu pula sebaliknya (Iryani, 2009). Jadi keberhasilan dari teknologi maupun sistem informasi pada perusahaan atau organisasi bergantung pada seberapa baik pengguna mampu menerapkan aplikasi tersebut secara baik dan menerapkannya dengan baik 
Kemampuan teknik personal dapat diartikan sebagai kemampuan seseorang dalam mengoperasikan sistem dalam mengolah data menjadi sebuah informasi yang tepat, akurat, berkualitas serta dapat dipercaya bagi penggunanya. (Ives et. al. 1983) dalam penelitiannya menyatakan bahwa kemampuan teknik personal sistem informasi sebagai rata-rata pendidikan atau tingkat pengalaman dari pengguna. Oleh karena itu, setiap karyawan harus dapat menguasai penggunaan sistem berbasis komputer agar dapat memproses sejumlah transaksi dengan cepat dan terintegrasi, dapat menyimpan data dan mengambil data dalam jumlah yang besar, dapat mengurangi kesalahan matematik, menghasilkan laporan tepat waktu dalam berbagai bentuk, serta dapat menjadi alat bantu keputusan

SIA yang efektif adalah sistem yang mampu menghasilkan informasi yang berkualitas dan telah sesuai dengan tujuan perusahaan dalam penggunaan SIA tersebut. Oleh karena itu suatu perusahaan perlu memerhatikan faktor-faktor yang memengaruhi efektivitas penggunaan SIA. Efektivitas merupakan ukuran yang memberikan gambaran seberapa jauh target dapat dicapai, baik secara kualitas maupun waktu, orientasinya adalah pada keluaran (output) yang dihasilkan (Yamit, 2003:14). Secara umum sistem yang efektif didefinisikan sebagai sistem yang dapat memberikan pengaruh positif kepada pemakainya dan merupakan salah satu faktor yang signifikan dari keberhasilan manajemen dalam mencapai tujuan organisasi dan pengguna SIA memiliki peran besar dalam efektivitas sistem (Dehghanzade, 2011).

Kegunaan sistem informasi akuntansi dalam perusahaan dikatakan efektif tergantung pada seberapa baik pengguna mampu menggunakan aplikasi tersebut dan mengetahui dengan baik apa saja yang terdapat dalam sistem tersebut (Handoko, 2012). Namun dalam kenyataanya masih ada permasalahan yang sering muncul dalam penggunaan sistem infomrasi. Seperti masih terlambatnya dalam pembuatan laporan yang diakibatkan 
karyawan yang belum menguasai penggunaan sistem berbasis komputer yang nantinya akan membantu dalam memproses sejumlah transaksi dengan cepat dan terintegrasi. Oleh karena itu diperlukankannya pelatihan dan pendidikan untuk pengguna sistem agar meningkatnya kemampuan karyawan sehingga akan membantu pekerjaannya yang akan berdampak pada tercapainya visi dan misi perusahaan.

Pendidikan dan pelatihan merupakan upaya untuk pengembangan sumberdaya manusia, terutama untuk pengembangan aspek kemampuan intelektual dan kepribadian manusia (Notoatmodjo, 1992). Pendidikan dan pelatihan digunakan sebagai variabel moderasi, selain karena adanya ketidakonsistenan pada penelitian-penelitian sebelumnya variabel ini digunakan terkait mengenai teori Technology Acceptance Model (TAM). Teori TAM merupakan teori sistem informasi yang memuat model mengenai sikap individu untuk menerima dan menggunakan teknologi. Berdasarkan teori ini bahwa pendidikan dan pelatihan perlu diikuti oleh pengguna SIA. Pendidikan dan pelatihan dapat meningkatkan pemahaman pengguna mengenai manfaat yang diberikan atas penggunaan SIA dan memudahkan individu dalam penggunaannya. Pengguna SIA dalam perusahaan tentunya tidak akan langsung menerima dan menggunakan sistem informasi yang baru. Sebelum menerima sistem yang baru, pengguna terlebih dahulu akan mencari tahu manfaat dari perubahan tersebut dan kemudian akan berusaha untuk memahaminya. Hal tersebut dapat dicapai melalui pendidikan dan pelatihan yang tepat. Pendidikan dan pelatihan kepada karyawan sangat dibutuhkan agar karyawan lebih terampil dalam menggunakan SIA, sehingga program pendidikan dan pelatihan tersebut akan memberikan keuntungan kepada para karyawan dan pengguna sistem dalam menjalankan kegiatan operasional perusahaan (Wilkinson, 2000:557). 
Sistem informasi akuntansi tidak hanya digunakan di Perusahaan Dagang tetapi juga sangat diperlukan dalam lembaga keuangan seperti LPD. LPD merupakan suatu lembaga keuangan milik Desa Pakraman yang memberikan pelayanan kepada masyarakat, baik itu berupa pinjaman ataupun tempat penyimpanan uang untuk masyarakat. Tujuan didirikannya LPD adalah untuk membangun dan mengembangkan potensi dan kemampuan ekonomi masyarakat di pedesaan untuk meningkatkan kesejahteraan ekonomi dan sosialnya. Selain itu didirikannya LPD berperan serta secara aktif dalam upaya mempertinggi kualitas kehidupan manusia dan masyarakat.

Berkembangnya sebuah LPD menunjukan adanya volume transaksi yang semakin besar sehingga kompleksitas pengolahan data semakin tinggi (Utari, 2014). Penggunaan SIA pada LPD berperan dalam memudahkan karyawan untuk pemprosesan data agar lebih praktis. Hal ini penting karena Perda No. 4 Tahun 2012 menyatakan bahwa LPD harus menerapkan prinsip ketelitian dalam pengelolaan LPD. Prinsip ketelitian tersebut meliputi peraturan mengenai kecukupan modal, Batas Maksimum Pemberian Pinjaman (BMPK), penyisihan Cadangan Pinjaman Ragu-Ragu (CPRR) untuk menutup jika terjadi kerugian pinjaman, manajemen likuiditas, sistem penilaian kesehatan LPD, sistem penilaian peringkat risiko LPD dan kewajiban penyampaian laporan LPD (LPLPD Provinsi Bali, 2014). Fenomena yang terjadi sekarang ini masih banyak LPD yang belum didukung dengan sistem informasi akuntansi yang memadai. Seperti halnya LPD di Kecamatan Kediri, peneliti menemukan indikasi masih ada LPD yang belum menggunakan SIA. Kondisi persaingan yang semakin kompetitif juga menjadi alasan pemilihan tempat penelitian, telah banyak lembaga keuangan selain LPD seperti koperasi dan bank berkembang di Kecamatan Kediri. Kondisi persaingan yang kompetitif ini menuntut LPD di Kecamatan Kediri untuk menunjukan keunggulannya yaitu dengan penggunaan SIA 
dengan program aplikasi agar mampu menghasilkan informasi akuntansi yang berkualitas sehingga mendukung proses pengambilan keputusan yang tepat dan dapat meningkatkan pelayanan kepada nasabah.

Penelitian ini dilakukan karena ada ditemukannya permasalahan mengenai kecurangan di dalam hal pencatatan tabungan dan deposito pada LPD Desa Pakraman Cepaka yang dilakukan oleh petugas pencatat tabungan dan deposito nasabah, dalam pembukuan di komputer LPD tersebut. Hal ini menyebabkan sejumlah nasabah LPD Cepaka merasa resah dengan permasalahan tersebut. Dengan ditemukan masalah tersebut, maka peneliti mengambil judul "Pengaruh Kinerja Individual dan Kemampuan Teknik Personal pada Efektivitas Sistem Informasi Akuntansi dengan Pendidikan dan Pelatihan Sebagai Variabel Moderasi" bertujuan untuk mengetahui seberapa besar pengaruh dari SIA. Hasil penelitian ini diharapkan dapat menjadi bahan pertimbangan bagi pihak LPD di Kecamatan Kediri untuk meningkatkan efektivitas penggunaan SIA dan menjadi sumber informasi bagi peneliti berikutnya terkait mengenai efektivitas penggunaan SIA.

Menurut DeLone dan McLean (1992) mengatakan bahwa kinerja individu atau pemakai (user) yang baik mampu meningkatkan efektivitas sistem informasi akuntansi. Sistem informasi akuntansi yang efektif adalah sistem yang dapat menghasilkan informasi yang berkualitas.

Hasil penelitian oleh Awesejo (2013), Suratini (2015), Antasari (2015), Arsiningsih (2015), menemukan pengaruh positif antara kinerja karyawan terhadap efektivitas sistem informasi akuntansi. Hasil tersebut menunjukan bahwa efektivitas penerapan sistem informasi akuntansi dapat meningkat apabila didukung dengan kinerja karyawan yang baik. Berdasarkan uraian diatas maka di rumuskan hipotesis sebagai berikut. 
H1 : Kinerja Individual berpengaruh terhadap Efektivitas Sistem Informasi Akuntansi.

Penggunaan sistem informasi dalam suatu organisasi yang didukung oleh meningkatnya kemampuan personal akan membuat sistem informasi dapat berjalan dengan efektif dan mampu meningkatnya kinerja organisasi. Adapun beberapa penelitian sebelumnya mengenai kemampuan teknik personal yang konsisten, seperti pada penelitian Irma (2014) menunjukan bahwa kemampuan teknik personal berpengaruh positif dan signifikan pada efektivitas penerapan SIA. Sejalan dengan penelitian Deni (2015) mengenai Analysis Of Factors Affecting The Success Of The Application Of Accounting Information System menunjukan bahwa kompetensi pengguna mempengaruhi kualitas SIA.

Hal ini juga didukung dengan penelitian yang dilakukan oleh Prabowo (2013), Wilayanti dan Dharmadiaksa (2016), Adisanjaya dkk. (2017) yang memperoleh hasil bahwa kemampuan personal berpengaruh positif dan signifikan terhadap efektivitas sistem informasi. Dimana kemampuan personal disini berkaitan dengan kemampuan yang dimiliki oleh pemakai sistem informasi akuntansi, sehingga semakin tinggi kemampuan personal seseorang maka akanmeningkatlan efektivitas sistem informasi akuntansi yang ada. Berdasarkan uraian diatas maka dirumuskan hipotesis sebagai berikut :

\section{H2 : Kemampuan TeknikPersonal berpengaruh terhadap Efektivitas Sistem Informasi Akuntansi.}

Hasil penelitian yang dikemukakan oleh Syarfarudin (2001) pengetahuan seseorang merupakan usaha untuk mengoptimalisasi perubahan yang mungkin terjadi baik direncanakan maupun tidak sehingga dapat dikatakan tingkat pendidikan dan pelatihan seseorang dapat menunjang kinerja individual dalam efektivitas penggunaan sistem informasi akuntansi. 
Aditya dan Suardikha (2013) menyatakan bahwa setiap pelatihan mampu meningkatkan pengaruh tingkat kinerja karyawan terhadap efektivitas penggunaan sistem informasi akuntansi. Berdasarkan uraian di atas maka dirumuskan hipotesis sebagai berikut:

\section{H3 : Pendidikan dan Pelatihan memperkuat Kinerja Individual pada}

\section{Efektivitas Sistem Informasi Akuntansi}

Hasil penelitian Damana (2016), Putri (2015), Adisanjaya dkk (2017) menyatakan bahwa pelatihan dan pendidikan berpengaruh positif terhadap kinerja sistem informasi akuntansi. Pelatihan dan pendidikan yang dilaksanakan sangat diperlukan untuk menjelaskan kepada pengguna tentang penggunaan SIA sehingga meningkatkan kemampuan dan pemahaman karyawan terhadap SIA yang digunakan sehingga karyawan merasa puas karena dapat menjalankan sistem tersebut dan akan terus menggunakan SIA dalam setiap proses kegiatannya untuk meningkatkan kinerja dan berdampak pada meningkatnya efektivitas penggunaan SIA sehingga tujuan perusahaan dapat tercapai.

Almilia dan Brilliantine (2007), menyatakan bahwa kinerja sistem informasi akuntansi akan lebih tinggi apabila program pelatihan dan pendidikan pemakai diperkenalkan. Jadi, keberhasilan penerapan suatu sistem informasi dapat diwujudkan dengan memperbanyak kegiatan pelatihan dan pendidikan pada karyawan yang akan

meningkatkan kemampuan teknik personal dalam penggunaan SIA. Pendidikan dan pelatihan tidak hanya menambah pengetahuan karyawan, tetapi juga dapat meningkatkan keterampilannya dalam bekerja, dengan demikian produktivitas kerja dapat meningkat. Pendidikan dan pelatihan akan membantu pemakai sistem untuk memahami dan dapat menggunakan sistem informasi yang ada sehingga dapat meningkatkan efektivitas 
penggunaan Sistem Informasi Akuntansi. Berdasarkan pada uraian diatas maka dirumuskan hipotesis sebagai berikut:

\section{H4 : Pendidikan dan Pelatihan Memperkuat Kemampuan Teknik Personal}

\section{pada Efektivitas Sistem Informasi Akuntansi}

\section{METODE PENELITIAN}

Penelitian ini dilakukan pada seluruh LPD di Kecamatan Kediri yang berbasis SIA. Objek dari penelitian ini adalah pengaruh kinerja individual dan kemampuan teknik personal pada efektivitas sistem informasi akuntansi dengan pendidikan dan pelatihan sebagai pemoderasi pada LPD di Kecamatan Kediri.

Variabel bebas yang terdapat dalam penelitian adalah kinerja individual (X1) dan kemampuan teknik personal (X2). Variabel terikat yang terdapat dalam penilitian ini yaitu efektivitas sistem informasi akuntansi (Y). Variabel moderasi dalam penelitian ini yaitu pendidikan dan pelatihan (X3). Penggunaan jenis data dalam penelitian ini adalah data kuantitatif merupakan jawaban responden yang telah dikuantitatifkan dengan skala likert. Data kualitatif merupakan daftar LPD di Kecamatan Kediri yang berjumlah 21 LPD. Sumber data dalam penelitian ini berupa data primer yaitu jawaban yang diberikan responden terhadap kuesioner yang dikumpulkan dari LPD di Kediri dan data sekunder dalam penelitian ini yaitu data mengenai jumlah, nama dan LPD di Kecamatan Kediri. Populasi dalam penelitian ini adalah LPD yang terdapat di Kecamatan Kediri. Penentuan sampel dari penelitian ini menggunakan teknik sampling jenuh, dimana semua LPD dijadikan sampel.

Teknik penentuan sampel dalam hal ini adalah dengan menggunakan metode purposive sampling yaitu metode penentuan sampel dengan pertimbangan tertentu dimana 
anggota-anggota sampel akan dipilih sedemikian rupa sehingga dapat mewakili sifat-sifat populasi. Kriteria responden yang dipilih pada penelitian ini terdiri dari 1 manajer LPD, 1 karyawan pada bagian pembukuan, 1 karyawan pada bagian kasir, dan minimal berpendidikan SMA/sederajat pada 21 LPD yang terdapat di Kecamatan Kediri. Alasan pengambilan tiga responden tersebut sebagai sampel dan mewakili seluruh populasi dalam penelitian ini yaitu karena tiga responden tersebut sudah pasti mengaplikasikan sistem di LPD masing-masing. Jadi penulisan sampel sejalan dengan penelitian ini dan tepat ditujukan dengan orang-orang tersebut mengenai sistem informasi akuntansi yang efektif. Metode pengumpulan data pada penelitian ini menggunakan instrumen kuisioner yang disebarkan secara langsung kepada responden dan dijawab sendiri oleh responden tersebut. Skala pengukuran yang digunakan dalam kuisioner tersebut adalah skala Likert.Kuisioner yang disebar berupa daftar pernyataan tertulis kepada responden mengenai pengaruh tingkat pendidikan, pelatihan, prestasi, pengalaman kerja terhadap efektivitas penggunaan sistem informasi akuntansi. Berikut ini bobot penilaian skala Likert.

\section{HASIL DAN PEMBAHASAN}

Pengujian hipotesis dalam penelitian menggunakan analisis Regresi sedangkan untuk variabel moderasi menggunakan Uji Residual. Hasil perhitungan disajikan pada Tabel 1.

Tabel 1

Tabulasi Output SPSS

\begin{tabular}{|l|c|c|l|}
\hline \multicolumn{1}{|c|}{ Variabel } & $\begin{array}{c}\text { Standardized } \\
\text { Beta }\end{array}$ & $\begin{array}{c}\text { Probabilitas } \\
\text { (sig.) }\end{array}$ & Keterangan \\
\hline Konstanta & $-1,876$ & 0.597 & \\
\hline Kinerja Individual (KI) & 0.458 & 0.000 & Signifikan \\
\hline Kemamputan Teknik Personal (KTP) & 0.258 & 0.045 & Signifikan \\
\hline Pendidikan dan Pelatihan (PP) & 0.268 & 0.002 & Signifikan \\
\hline Adjusted R Square & 0.825 \\
\hline F Statistik & 98.279 \\
\hline Probabilitas (p-value) & 0,000 \\
\hline \multicolumn{3}{||}{ Uji Residual } \\
\hline Lack of fit (KI dan PP) & 0.037 & 0.773 & Tidak Signifikan \\
\hline
\end{tabular}




\section{Sumber: Hasil Pengolahan Data}

Nilai adjusted $\mathrm{R}$ square sebesar 0,825 menunjukkan bahwa $82,5 \%$ variasi nilai Efektivitas Sistem Informasi Akuntansi dapat dijelaskan oleh faktor-faktor Kinerja Individual, Kemampuan Teknik Personal dan Pendidikan Pelatihan. Sedangkan sisanya sebesar $17,5 \%$ dipengaruhi oleh faktor lain yang tidak diamati dalam penelitian ini. Signifikasi Lack of fit memikili nilai diatas 0,05 menyatakan bahwa tidak terjadi interaksi antara variabel independen dengan variabel moderasi yang dapat memengaruhi variabel dependen.

\section{Pengaruh Kinerja Individual pada Efektivitas Sistem Informasi Akuntansi}

Berdasarkan hasil pengujian hipotesis pada Tabel Tabulasi menyatakan hipotesis 1 diterima. Hasil ini menunjukkan bahwa semakin tinggi Kinerja Individual maka kecenderungan Efektivitas Sistem Informasi Akuntansi juga semakin tinggi. Penerimaan hipotesis ini juga diperkuat oleh beberapa hasil penelitian sebagai berikut.

Hasil penelitian oleh Awesejo (2013), Suratini (2015), Antasari (2015), Arsiningsih (2015), menemukan pengaruh positif antara kinerja karyawan terhadap efektivitas sistem informasi akuntansi. Hasil tersebut menunjukan bahwa efektivitas penerapan sistem informasi akuntansi dapat meningkat apabila didukung dengan kinerja karyawan yang baik.

\section{Pengaruh Kemampuan Teknik Personal pada Efektivitas Sistem Informasi}

\section{Akuntansi}

Berdasarkan hasil pengujian hipotesis pada tabel Tabulasi, menyatakan hipotesis 2 diterima. Hasil ini menyatakan bahwaKemampuan Teknik Personalmempengaruhi Efektivitas Sistem Informasi Akuntansi. Semakin tinggi kemampuan teknik personal maka 
dapat meningkatkan efektivitas sistem informasi akuntansi. Hasil ini juga diperkuat oleh beberapa penelitian sebagai berikut.

Hal ini juga didukung dengan penelitian yang dilakukan oleh Prabowo (2013), Wilayanti dan Dharmadiaksa (2016), Adisanjaya dkk. (2017) yang memperoleh hasil bahwa kemampuan personal berpengaruh positif dan signifikan terhadap efektivitas sistem informasi.Dimana kemampuan personal disini berkaitan dengan kemampuan yang dimiliki oleh pemakai sistem informasi akuntansi, sehingga semakin tinggi kemampuan personal seseorang maka akanmeningkatlan efektivitas sistem informasi akuntansi yang ada. Oleh karena itu, untuk mengurangi terjadinya kesalahan dalam memproses sejumlah transaksi setiap karyawan diharapkan dapat menguasai penggunaan sistem berbasis sehingga laporan keuangan yang dihasilkan dapat tepat waktu dan bermanfaat.

Pengaruh Moderasi Pendidikan dan Pelatihan pada hubungan Kinerja Individual dan Efektivitas Sistem Informasi Akuntansi

Teori Technology Acceptance Model (TAM) merupakan teori sistem informasi yang memuat model mengenai sikap individu untuk menerima dan menggunakan teknologi. Berdasarkan teori ini bahwa pendidikan dan pelatihan perlu diikuti oleh pengguna SIA. Pendidikan dan pelatihan dapat meningkatkan pemahaman pengguna mengenai manfaat yang diberikan atas penggunaan SIA dan memudahkan individu dalam penggunaannyan, 2000:557).

Berdasarkan hasil pengujian hipotesis pada tabel Tabulasi, menyatakan hipotesis 3 ditolak karena lack of fit (ketidakcocokan) interaksi antara variabel kinerja individual dengan pendidikan dan pelatihan tidak berpengaruh pada efektivitas sistem informasi akuntansi. Dapat disimpulkan bahwa pendidikan dan pelatihan tidak mampu memoderasi hubungan kinerja individual dan efektivitas sistem informasi akuntansi, dalam penelitian 89| widya_akuntansi 
ini menunjukan bahwa pendidikan dan pelatihan yang diikuti oleh pegawai LPD di Kecamatan Kediri kurang efektif,dilihat dari hasil evaluasi (kuisioner) setelah diadakan pendidikan dan pelatihan tidak terjadi perubahan sikap dan perilaku pada diri pegawai dalam menyelesaikan pekerjaan.Faktor yang menghambat dari variabel pendidikan dan pelatihan dalam penelitian ini ialah karena faktor karakteristik subyek dalam penelitian ini berbeda dari penelitian sebelumnya.

\section{Pengaruh Moderasi Pendidikan dan Pelatihan pada hubungan Kemampuan} Teknik Personal dan Efektivitas Sistem Informasi Akuntansi.

Teori Technology Acceptance Model (TAM) merupakan teori sistem informasi yang memuat model mengenai sikap individu untuk menerima dan menggunakan teknologi. Berdasarkan teori ini bahwa pendidikan dan pelatihan perlu diikuti oleh pengguna SIA. Pendidikan dan pelatihan dapat meningkatkan pemahaman pengguna mengenai manfaat yang diberikan atas penggunaan SIA dan memudahkan individu dalam penggunaannya

Berdasarkan hasil pengujian hipotesis pada tabel Tabulasi, menyatakan hipotesis 4 ditolak karena lack of fit (ketidakcocokan) interaksi antara variabel kemampuan teknik personal dengan pendidikan dan pelatihan tidak berpengaruh pada efektivitas sistem informasi akuntansi. Dapat disimpulkan bahwa pendidikan dan pelatihan tidak mampu memoderasi hubungan kemampuan teknik personal dan efektivitas sistem informasi akuntansi. Pendidikan dan pelatihantidak serta merta dapat mempengaruhi kemampuan teknik personal karena dalam hal ini faktor tempat dan subyek menjadi salah satu karakteristik untuk hal tersebut.

\section{KESIMPULAN DAN SARAN}

Berdasarkan hasil pembahasan analisis data melalui pembuktian terhadap hipotesis, maka simpulan yang dapat diambil adalah sebagai berikut. (1) Kinerja Individual 
berpengaruh positif pada Efektivitas Sistem Informasi Akuntansi. Hal ini menunjukkan bahwa semakin tinggi kinerja individual maka efektivitas sistem informasi akuntansijuga akan meningkat; (2) Kemampuan Teknik Personal berpengaruh positif pada Efektivitas Sistem Informasi Akuntansi. Hal ini menunjukkan bahwa semakin tinggi kemampuan teknik personal maka efektivitas sistem informasi akuntansi juga akan meningkat; (3) Pendidikan dan Pelatihan tidak memperkuat hubungan positif antara kinerja individual dan efektivitas sistem informasi akuntansi. Hasil penelitian menyatakan kegiatan pendidikan dan pelatihan tidak mampu mempengaruhi interaksi antar variabel kinerja individual dan efektivitas sistem informasi akuntansi; (4)Pendidikan dan Pelatihan tidak memperkuat hubungan positif antara kemampuan teknik personal dan efektivitas sistem informasi akuntansi. Hasil penelitian menyatakan kegiatan pendidikan dan pelatihan tidak mampu mempengaruhi interaksi antar variabel kemampuan teknik personal dan efektivitas sistem informasi akuntansi.

Berdasarkan hasil simpulan, maka saran yang dapat diberikan adalah sebagai berikut : (1) Sebaiknya sistem informasi akuntansi yang ada pada LPD di Kecamatan Kediri selalu dijaga kemuktahirannya sehingga selalu dapat mendukung akses kerja karyawan guna kinerja karyawan menjadi lebih baik; (2) Karyawan LPD di Kecamatan Kediri disarankan untuk meningkatkan kemampuan teknik personal dalam menggunakan sistem komputer agar efektivitas sistem informasi akuntansi juga meningkat; (3) Diharapkan dalam pengadaan pendidikan dan pelatihan diperlukan individu yang memiliki komitmen kinerja yang baik dan berkompeten untuk siap menerima masukan ilmu agar mampu mengoprasikan sistem dan menerapkan sistem informasi akuntansi secara efektif. 


\section{DAFTAR PUSTAKA}

Adisanjaya, Komang., Wahyuni, Made Ari., Purnamawati, I Gusti Ayu. 2017. Pengaruh Kemampuan Personal, Pelatihan dan Pendidikan serta Pemanfaatan Teknologi Terhadap Efektivitas Sistem Informasi Akuntansi Pada Mini Market Bali Mardana. E-Journal S1 Akuntansi Universitas Pendidikan Ganesha,7(1), hal.1-18

Aditya, Puja Pratama. dan Suardikha, I Md. Sadha. 2013. Keahlian Pemakai Komputer dan Kenyamanan Fisik Memoderasi Pengaruh Efektivitas Sistem Informasi Akuntansi Terhadap Kinerja Karyawan di PT. Bank Sinar Harapan Bali Denpasar. E-Jurnal Akuntansi Universitas Udayana, 5(2), pp: 361-38

Almilia, Luciana Spica dan Briliantien. 2007. Faktor-faktor yang Mempengaruhi Kinerja Sistem Informasi Akuntansi pada Bank Umum Pemerintah di Wilayah Surabaya dan Siduarjo. Jurnal Ilmiah. STIE Perbanas. Surabaya.

Alsarayreh, M.N.O.A.A., Jawabreh, M.M.F. Jaradat, dan S.A Alamro. 2011. Technological Impacts on Effectiveness of Acccounting Information Systems (AIS) Applied by Aqaba Tourist Hotels. European Journal of Scientific Research. Vol 59. No. 3 : 361369.

Arikunto, Suharsimi. (2006). Prosedur Penelitian Suatu Pendekatan Praktik. Jakarta:Rineka Cipta.

Awesejo, O.J., Kekwaletswe, R, M., Pretorius, P and Zuva, T. 2013. The Effect of Accounting Information System in Accounting. 3(1), pp:142-150

Awosejo, Oluwaseun J., Kekwaletswe, Raymond M., and Pretorius, Pieter. 2014. Recommendation of Information Systems to Motivate Accounting Firm in South Africa. Tshwane University of Technology, Department of Informatics, Soshanguve South Campus, Pretoria, South Africa, 2(4), pp.77-85.

Bodnar, G, H dan Hopwood, W.S. (Amir Abadi Jusup dan Rudi M. Tambunan, penerjemah). 2001. Sistem Informasi Akuntansi. Salemba Empat, Jakarta.

Chloe, J.M. 1996. The Relationship Among Performance Of Accounting Information System, Influence Factors, And Evolution Level Of Information Systems. Journal of Management Information System, 12(4), pp.215-239.

Dehghanzade, H., Moradi, M. A., \& Raghibi, M. (2011). A Survey of Human Factors' Impacts on the Effectiveness of Accounting Information Systems. International Journal of Business Administration, 2(4), 166.

DeLone, W., dan McLean, E.R. Information System Suces : The Qusets for Dependent Variable, Information System Research, (3:1). 1992. Pp. 60-95.

Deni Iskandar. 2015. Analysis of Factors Affecting The Success of The Application of Accounting Information System. International Journal of Scientific \& Technology Research Volume 4, Issue 02. February 2015. 
Edison, G., Manuere, F, Joseph, M., And Gutu, K. 2012. Evaluation of Factors Influencing Adoption of Acounting Information by Small to Medium Enterprises in Chinhoyi. Journal of Contemporary Research in Bussiness, 4(6), pp: 1126-1141.

Ghozali, Imam. 2006. Aplikasi Analisis Multivariate dengan Program SPSS.

Semarang: Badan Penerbit Universitas Diponegoro.

Handoko, T. Hani. 2012. Manajemen Personalia dan Sumber Daya Manusia. Yogyakarta: BPFE.

Irma Diana Putri. 2014. Pengaruh Kemampuan Teknik Personal, Program Pelatihan dan Pendidikan Pemakai, Insentif dan Partisipasi Manajemen pada Kinerja Penerapan Sistem Informasi Akuntansi. Skripsi S-1 Jurusan Akuntansi Universitas Udayana.

Iryani, Christine. 2009. Pengaruh Efektivitas Penggunaan dan Kepercayaan pada Teknologi Sistem Informasi Terhadap Kinerja Individual di PT. PLN (Persero) Distribusi Bali Area Pelayanan Gianyar. Skripsi S-1 Jurusan Akuntansi Fakultas Ekonomi Universitas Udayana.

Ives, Blake; Margrethe H. Olson; dan Jack Joseph Baroudi. 1983. The Measurement of User Information Satisfaction. NYU Working Paper No. 1S-82-27.

Krahel and Vasarhelyi. 2014. AIS as a Facilitator of Accounting Change: Technology, Practice, and Education: Journal of Information Systems, 28(2), pp.1-15.

LPLPD Provinsi Bali. 2014. Pelatihan Standarisasi Karyawan LPD Kabupaten / Kota se Bali

Mahendra, A. R., dan Affandy, D. P. 2013. Faktor-Faktor yang Mempengaruhi Minat Pemanfaatan Sistem Informasi Pengelola Keuangan Daerah (SIPKD) (Studi Kasus pada Pemerintah Kota Blitar). Jurnal Ilmiah Mahasiswa FEB, 1(2), hal.1-26.

Mahmudi. 2010. Manajemen Kinerja Sektor Publik. Edisi Kedua. Yogyakarta: UPP STIM YKPN.

Mahsun, Mohammad. 2006. Pengukuran Kinerja Sektor Publik. Edisi Pertama. Yogyakarta: BPFE.

Mangkuprawira, S. 2003. Manajemen Sumber Daya Manusia Strategik. Cetakan Kedua. Ghalia Indonesia, Jakarta.

Medina, Jose Melchor., Jimenez Karla., Mora Alberto., Abrego Demian. 2014. Training in Accounting Information Systems fot Users Satisfaction and Decision Making. International Journal of Bussiness and Social Science, 5(7), pp.134-144

Mulyadi. 2016. Sistem Akuntansi. Jakarta: Salemba Empat. 
Murty, W. Aprilia, dan Hudiwinarsih Gunasti. 2012. Pengaruh Kompensasi, Motivasi dan Komitemen Organisasional terhadap Kinerja Karyawan Bagian Akuntansi. Jurnal STIE Perbanas, 2 (2), h:215-228.

Nabizadeh, Seyed Mohammadali dan Seyed Ali Omrani. 2014. Effective Factors on Accounting Information System Alignment; A Step Towards Organizational Performance Improvement. International Journal of Scientific and Research Publications. Volume 4, Issue 9, September 2014.

Notoatmodjo, Soekidjo. 1992. Pengembangan Sumber Daya Manusia. Jakarta: PT Rineka Cipta.

Nurjaya,I Nyoman Prof.Dr MH SH. Lembaga Perkreditan Desa di Bali Dalam Perspektif Antropologi Hukum Denpasar

Ogah, Idagu Joseph. 2013. An Evaluation of the Relevance of Accounting Systems as a Management Decision Tool in Union Bank of Nigeria Plc, Uyo Branch of Akwa Ibom. Greener journal of Business and Management Business Study, 3 (1), pp.38-45.

Prabowo, Rizki Respati. 2013. Faktor-Faktor Yang Mempengaruhi Kinerja Sistem Informasi Akuntansi Pada Bank Umum Kota Surakarta. JUPE UNS. 2(1), hal.119130.

Robbins, S.P. 2005. "Perilaku Organisasi : Konsep, Kontroversi, Aplikasi”. Edisi Bahasa Indonesia. Alih Bahasa oleh Hadyana Pujaatmaka. Penerbit Prenhallindo Jakarta.

Romney, Marshall B., dan Paul John Steinbart. 2015. Accounting Information Systems, 13th ed. England: Pearson Educational Limited.

Sari, Maria. M. Ratna 2009. Pengaruh Efektivitas Penggunaan dan Kepercayaan Terhadap Teknologi Sistem Informasi Akuntansi Terhadap Kinerja Individual pada Pasar Swalayam di Kota Denpasar. Jurnal Ilmiah Akuntansi dan Bisnis, 4(1).

Soudani, Siamak Nejadhosseini. 2012. The Usefulness of an Accounting Information System for Effective Organizational Performance. International Journal of Economics and Finance. 4(5), 136-143.

Spremic, Mario., Jakovic, Bozidar. 2012. The Impact of the Accounting System Usage on Companys' E-Business Efficiency. Annals \& Proceedings of DAAAM International, 23(1), pp.1068-1070.

Suratini, Ni Putu Eka. 2015. Pengaruh Efektivitas Sistem Informasi Akuntansi dan Penggunaan Teknologi Informasi Terhadap Kinerja Individual pada PT. Bank Pembangunan Daerah Bali Kantor Cabang Singaraja. E-Journal Akuntansi Universitas Pendidikan Ganesha S1. 3(1)

Sugiyono. 2014. Metode Penelitian Kombinasi.Bandung : Alfabeta. 
Sukandia,SH,MH, 2011. Sifat Suigenius Lembaga Keuangan Komunitas dalam pengaturan LPD sebagai lembaga keuangan komunitas masyarakat Desa Pakraman, Denpasar.

Swalhah, Ayyoub Al. 2014. The role of Accounting Information Systems (A.I.S.) in rationalized Administrative Decision- making (field study) Jordanian banks. Business Faculty, The World Islamic Sciences \& Education University, Jordan. 6(2), pp.1120.

Syarfarudin, Alwi. 2001. Manajemen Sumber Daya Manusia Strategi Keunggulan Komparatif. Edisi Kesatu. Yogyakarta. BPFE.

Urquia, Elena. 2011. An Effect of Accounting Information System on Performance Measure: Empirical Evidence in Spanish. Journal International of Digital Accounting Research, 11(2), pp:25-43.

Utari Sintia Dewi, N.M 2014. Pengaruh Kemampuan Teknik Pemakai Sistem Informasi Akuntansi, Partisipasi Manajemen, Intensif dan Faktor Demografi terhadap Kinerja Individu pada LPD di kota Denpasar: SkripsiS-1 Jurusan Akuntansi Universitas Udayana.

Wilayanti, Ni Wayan. 2015. Pengaruh Keterlibatan dan Kemampuan Teknik Personal pada Efektivitas Penggunaan Sistem Informasi Akuntansi Dengan Pendidikan dan Pelatihan sebagai Pemoderasi pada LPD di Kecamatan Tegalalang. Skripsi Akuntansi Universitas Udayana.

Wilayanti, Ni Wayan., dan Dharmadiaksa I.B. 2015. Pengaruh Keterlibatan dan Kemampuan Teknik Personal pada Efektivitas Penggunaan Sistem Informasi Akuntansi pada LPD di Kecamatan Tegalalang. E-jurnal Akuntansi Universitas Udayana 15(2), hal.1310-1337.

Wilkinson, Josep W, 2000, Accounting Information System Essential Concept and Application 4 Edition, John Willey \& Sons Inc, New York- USA

Yamit, Zulian, 2003, Manajemen Produksi dan Operasi. Edisi 2. Yogyakarta : Ekonisia

Zare, I. 2012. Study of Effect of Accounting Information System and Softwares on Qualitative Features of Accounting Information. Journal of Management Science and Business Research, 1(4), pp: 1-12. 